WORKING PAPER $\cdot$ NO. $2020-120$

\title{
Dust Bowl Migrants: Identifying an Archetype
}

Richard Hornbeck

AUGUST 2020

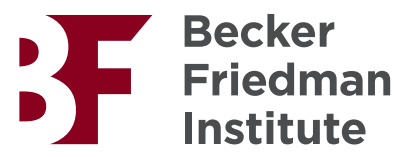


Dust Bowl Migrants: Identifying an Archetype

Richard Hornbeck

August 2020

JEL No. N32,N52

\begin{abstract}
The 1930's American Dust Bowl created archetypal "Dust Bowl migrants," refugees from environmental collapse and economic upheaval. I examine this archetype, comparing migration from more-eroded counties and less-eroded counties to distinguish Dust Bowl migrants from other migrants in this era. Migrants from more-eroded counties were more "negatively selected," in years of education, than other migrants who were "positively selected." These Dust Bowl migrants struggled economically, especially in California. Despite migrants' struggles, however, I estimate strikingly modest impacts of the Dust Bowl on average incomes that contrast with its enduring impacts on agricultural land.
\end{abstract}

Richard Hornbeck

Booth School of Business

University of Chicago

5807 South Woodlawn Avenue

Chicago, IL 60637

and NBER

richard.hornbeck@chicagobooth.edu 
During the American Dust Bowl of the 1930's, many Plains counties experienced substantial erosion. Agricultural land values declined in more-eroded counties, relative to less-eroded counties, and more-eroded counties experienced relative declines in population through the 1950's (Hornbeck, 2012). During the 1930's, amidst the Great Depression, the notable experiences of migrants to California became associated with those of "Dust Bowl migrants" and their suffering came to represent a breakdown of the American economy.

Dust Bowl migrants became an archetype, refugees displaced by environmental collapse and economic upheaval. This lasting impression of the Dust Bowl migrants was established, and remains prominent, largely through artistic works: John Steinbeck's novel "The Grapes of Wrath" and its film; Dorothea Lange's photography, including "Migrant Mother, Nipomo, California;" and Woody Guthrie's "Dust Bowl ballads." ${ }^{1}$ There have also been data efforts to characterize the Dust Bowl migrants, including contemporaneous analysis of surveyed migrant families in California (Janow and McEntire, 1940) and subsequent analysis of migrants in Census data samples (Gregory, 1989; Long and Siu, 2018). A substantial challenge is that "Dust Bowl migrants," those induced to move by the Dust Bowl itself, are difficult to separate from other migrants in this era who were induced to move by the Great Depression, New Deal policies, agricultural mechanization, broader drought, and other factors (Bogue and Hagood, 1953; Fishback, Horrace and Kantor, 2006; Boustan, Fishback and Kantor, 2010; Gutmann et al., 2016). Understanding who these Dust Bowl migrants were, and how they differed from other migrants in this era, can identify this archetypal migrant, clarify how migration responded to this environmental collapse and associated economic upheaval, and help understand why this migration generated local hostility and national empathy. Further, by following both migrants and non-migrants, an analysis can move beyond identifying impacts of the Dust Bowl on more-eroded counties (Hornbeck, 2012) and identify impacts of the Dust Bowl on people from more-eroded counties.

This paper examines the Dust Bowl migration, estimating how the intensity of countylevel erosion influenced migration rates and the characteristics of those who migrated. The paper identifies these archetypal "Dust Bowl migrants" and how they differed from general Depression-era migrants from similar counties. The analysis uses the full 1940 US Census, which asked people their 1935 county of residence, in comparing migrants to non-migrants in their 1935 county (out-selection) and comparing migrants to natives in their 1940 county (in-selection). These data also allow for the first assessment of how the Dust Bowl impacted wage incomes in 1939, including those who remained and those who migrated.

Migration represents a main channel of adaptation to local environmental destruction, but the experiences of migrants and their reception in new locations depends importantly on

\footnotetext{
${ }^{1}$ See Shindo (1997) and Lookingbill (2001) for cultural histories of these artistic works.
} 
who migrates in response to this environmental collapse. Migrants are generally "selected" because the relative returns or costs of migration generally differ across individuals. Further, when people can plan for future migration, they may invest more in education or skills that are relatively more productive in new locations. Thus, the people who migrate after unanticipated large shocks may differ from those who migrate in typical circumstances. Environmental shocks may also generate different migration responses than other economic shocks, and permanent environmental changes may generate differential migration responses than temporary environmental shocks. The Dust Bowl migrants are of particular historical interest, as they have become an archetype of environmental refugees, and the Dust Bowl migrants represent a rare opportunity to explore migration responses to a permanent and unanticipated collapse in the local environment.

My empirical analysis compares migrants from more-eroded counties to migrants from less-eroded counties within the same state and with similar pre-1930's characteristics, extending the empirical specification from Hornbeck (2012). I measure migration using individuals' reported county of residence in 1935 and 1940, rather than matching individuals across Censuses, which reduces the potential for spurious migration (and biased migrant characteristics) and includes women in the data (who may have changed last names). This period of analysis (1935 to 1940) coincides with the core Dust Bowl migration period, though there may have been some earlier migration and more-eroded counties continued to experience relative population declines into the 1950's. The empirical analysis cannot identify particular individuals as "Dust Bowl migrants," but this analysis identifies how, on average, the Dust Bowl induced different migrants.

I estimate that migration rates were higher from more-eroded counties than from lesseroded counties. Overall, 7\% of 1935 Plains residents had, by 1940, moved to a county more than 200 miles away. This migration rate was 2.6 percentage points higher from higherosion counties and 1.4 percentage points higher from medium-erosion counties, relative to low-erosion counties within the same state and with similar pre-1930's characteristics. Migration to California was not the typical response (1.65\% of 1935 Plains residents), but this migration rate to California was 0.70 percentage points higher from high-erosion counties and 0.51 percentage points higher from medium-erosion counties. ${ }^{2}$

Migrants from more-eroded counties were more "negatively selected," in years of education, than other migrants in this era who were generally "positively selected." That is, while migrants generally had more years of education than those who remained in their 1935 counties, this was less true of migrants from more-eroded counties. Further, when focusing

\footnotetext{
${ }^{2}$ I also estimate elevated migration to the Pacific Northwest (Washington, Oregon, Idaho), though experiences of migrants in California have been more central in the narrative surrounding Dust Bowl migrants.
} 
on "Dust Bowl migrants," or only those additional migrants induced to move by higher erosion, they had fewer years of education than non-migrants. Along other characteristics, migrants generally were younger and more likely male; and along these characteristics, Dust Bowl migrants were similar to general migrants.

Migrants from more-eroded counties also had lower incomes in 1939, compared to natives in their new destinations, than migrants from less-eroded counties. Further, migrants from all Plains counties had lower incomes than natives, and especially so in California. Thus, while Dust Bowl migrants fared worse relative to natives, much of the story is that all migrants struggled relative to natives and there were elevated rates of migration from more-eroded counties.

Finally, I estimate strikingly modest impacts of the Dust Bowl on 1939 incomes for all 1935 residents of more-eroded counties, given the substantial economic struggles of Dust Bowl migrants and enduring impacts on agriculture in more-eroded counties. Agricultural land values declined substantially in more-eroded counties with limited adaptation in local agricultural production (Hornbeck, 2012), yet I estimate only modest differences in 1939 wage incomes between all 1935 residents of more-eroded counties and all 1935 residents of less-eroded counties (including migrants and non-migrants).

This paper relates to a broad literature on migration, which represents an important margin of economic adaptation. The Dust Bowl provides a rare opportunity to explore migration responses to a permanent collapse in the local environment, in contrast to more exploration of migration responses to more-temporary natural disasters and weather shocks (Piguet, Pécoud and de Guchteneire, 2011; Boustan, Kahn and Rhode, 2012; Marchiori, Maystadt and Schumacher, 2012; Bohra-Mishra, Oppenheimer and Hsiang, 2014; Cai et al., 2016; Deryugina, 2017; Deryugina, Kawano and Levitt, 2018; Boustan et al., 2019; Deryugina and Molitor, 2019; Mahajan and Yang, 2020; Spitzer, Tortorici and Zimran, 2020). The migration literature has long considered how migrant selection varies across contexts (Roy, 1951; Borjas, 1987), and characterizing the Dust Bowl migrants and their experiences provides an opportunity to refine this archetype of environmental refugee. Indeed, future changes in climate are expected to generate substantial migrant flows (Stern, 2007), which may have important roles in mitigating economic costs of climate change (Desmet and Rossi-Hansberg, 2015), but these migration responses may differ from migration patterns observed today. The Dust Bowl period highlights how a permanent collapse of the local environment generated less positively-selected migrants, who struggled relative to natives in their new destinations, but were ultimately the most substantial margin of economic adaptation.

In focusing on migration from environmental collapse, this episode also complements our understanding of how the United States has been influenced by large-scale migration, such 
as the Great Migration of African Americans to the Northern United States (Collins and Wanamaker, 2014, 2015) and the age of mass migration to the United States (Abramitzky, Boustan and Eriksson, 2012; Abramitzky and Boustan, 2017). Who migrates, and how they differ from natives in their new destinations, influences how migrants are received in their new destinations and what impacts migrants have on those destinations (Boustan, 2009, 2010; Boustan, Fishback and Kantor, 2010; Derenoncourt, 2019).

\section{Empirical Context}

Amidst economic turmoil in the 1930's, the United States' Plains experienced widespread severe erosion in what became known as the Dust Bowl. Especially severe droughts in 1934 and 1936, and loss of ground cover, made topsoil susceptible to large dust storms (e.g., "Black Sunday" in 1935) and substantial water erosion during occasional rains. There was uncertainty concerning future regional weather, but local erosion was immediately clear: agricultural land values declined substantially by 1940, in more-eroded counties relative to less-eroded counties, and remained lower with limited adaptation in local agricultural production (Hornbeck, 2012).

The Dust Bowl became associated with imagery of displaced farmers migrating to California, and their economic struggles came to exemplify the combined experiences of the Dust Bowl, the Depression, and displacement by mechanization. In 1939, a special survey was conducted of migrant families with children in public schools, which highlighted this migration to California from Oklahoma (Janow and McEntire, 1940), with peak arrival years in 1936 and 1937. Migrants became derogatorily referred to as "Okies," though there was also substantial migration from Arkansas ("Arkies") and other non-Plains areas, which suggests this migration also reflected factors other than the Dust Bowl.

These migrants faced hostility, and even some efforts to block their entry into California. Stein (1973) argues that, while California had previously received large population inflows, native Californians turned against "Okies" because they were seen as atypically poor and undesirable. Contemporaries considered many of the "lowliest settlers" in California resettlement camps to be refugees from the Dust Bowl (e.g., Cannon, 1996, p. 102). ${ }^{3}$

Gregory (1989) uses the 1940 Census (1\% sample) to examine migrants to California, comparing all migrants from a broad region (Oklahoma, Texas, Arkansas, Missouri) to those who remained in their 1935 location and also how these "Southwestern" migrants compared to others in California in 1940. Gregory (1989) emphasizes that migration to California had been common, drawing relatively well-off migrants, but that 1935-40 migrants pushed from the Southwest were atypically worse-off. These migrants left for California not only due to

\footnotetext{
${ }^{3}$ There was also notable migration to the Pacific Northwest (Troxell and O'Day, 1940), where the selection of migrants and their experiences were seen as more moderate than for migrants to California (Dewing, 2006).
} 
the Dust Bowl, Stein and Gregory emphasize, but also mechanization, changing crop prices, and AAA policy. ${ }^{4}$

Long and Siu (2018) examine 4,210 individuals from 20 counties around the Oklahoma panhandle in 1930, who they compare to a national sample, and examine migration to California and other destinations. ${ }^{5}$ To measure migration, Long and Siu (2018) link individuals from the 1930 Census to the 1940 Census using their name, race, year of birth, and state of birth. ${ }^{6}$ Long and Siu (2018) find that panhandle-region migrants were not more likely to move to California, that farmers in the panhandle-region were least likely to move, and that there was negligible migrant selectivity. Long and Siu (2018) also emphasize that out-migration in the 1930's panhandle-region was not higher than the 1920's, though out-migration declined elsewhere over this time.

Identifying Dust Bowl migrants is about understanding who was induced to move by the Dust Bowl, and requires a counterfactual for who would have otherwise migrated. The panhandle-region and Southwestern-region differed substantially from the rest of the county, in 1930 and in changes over previous decades, and were affected differently by the Depression, AAA policy, mechanization, changing crop prices, and other shocks of the 1930's. The Dust Bowl was among many factors influencing migration in the 1930's (Fishback, Horrace and Kantor, 2006; Boustan, Fishback and Kantor, 2010; Gutmann et al., 2016), which would affect areas differently based on their agricultural production and other characteristics.

My analysis draws on Dust Bowl erosion throughout the Plains, comparing migration from more-eroded counties to migration from less-eroded counties within the same states and with similar pre-1930's county characteristics. Building on the county-level empirical specification in Hornbeck (2012), these relative comparisons identify average differences between Dust Bowl migrants and other Depression-era migrants. This helps separate what historical impressions of Dust Bowl migrants are a phenomenon of the Depression and other events of the 1930's, and in what ways this historical legacy should be attributed to the Dust Bowl itself and local environmental collapse. Further, by observing all 1935 residents of Plains counties (migrants and non-migrants), the analysis can move beyond estimating

\footnotetext{
${ }^{4}$ For recent empirical evidence on other push factors, see Fishback, Horrace and Kantor (2006) and Boustan, Fishback and Kantor (2010). In a more contemporary account, McWilliams (1942) focuses on mechanization and 1935-1939 migration from Oklahoma to California and the Pacific Northwest. Stuart and Taylor (2019) estimate weaker network effects among Plains white migrants than among Southern African American migrants during the Great Migration.

${ }^{5}$ Many of these panhandle-region counties experienced severe wind erosion but severe erosion was more widespread in the Plains (Hansen and Libecap, 2004) and these panhandle-region counties are outside areas of concentrated migration to California mapped by (Janow and McEntire, 1940).

${ }^{6}$ False-positive matches generate spurious migration and, indeed, $52 \%$ of panhandle-region residents are indicated to have moved counties, which would create biases if false-match rates vary across areas or individual characteristics.
} 
impacts of the Dust Bowl on more-eroded lands (Hornbeck, 2012) to estimate impacts of the Dust Bowl on the people who were living in more-eroded lands.

\section{Data}

Figure 1 shows a map of cumulative erosion damage after the Dust Bowl (Hornbeck, 2012). Dark gray areas are high-erosion (>75\% topsoil lost), light gray areas are medium-erosion, and white areas are low-erosion $(<25 \%$ topsoil lost). Because mapped erosion represents cumulative erosion after the Dust Bowl, rather than erosion that occurred only during the 1930's, the empirical analysis follows Hornbeck (2012) in controlling for pre-1930's county characteristics so the residual variation in erosion reflects differential erosion during the 1930's. This residual variation in erosion is strongly associated with 1930's declines in land value and population at the county level (Hornbeck, 2012).

Individual-level data are from the full 1940 Census, which includes individuals' county of residence in 1940 and 1935. These data include individuals' age, gender, education, whether they lived on a farm in 1935, and whether they lived in their birth state in 1935 . I restrict the analysis to individuals aged 25-55 in 1935, focusing on working-age individuals with completed education by 1935 . This sample includes 49.4 million individuals in the contiguous US with reported county of residence in 1940 and 1935, or 96.4\% of individuals aged 25-55 in $1935 .{ }^{7}$ The migration rate in county $c$ is defined as the number of individuals who moved from county $c$ to other counties, from 1935 to 1940, divided by the number of individuals in 1940 who report living in county $c$ in 1935.

County-level data are from the Census of Agriculture and Census of Population (Haines, 2010). These data capture a variety of Plains county characteristics in 1930, 1925, 1920, and 1910, which might be correlated with differential effects of the Depression and other shocks of the 1930's, such as agricultural mechanization and New Deal programs. These data are adjusted to county boundaries in 1940, following Hornbeck (2010), and merged with mapped erosion intensity.

\section{Empirical Specifications}

For estimating relative impacts of Dust Bowl erosion on migration rates from Plains counties, I regress the migration rate for county $c$ on: the fraction of the county in a high-erosion area $\left(H_{c}\right)$, the fraction of the county in a medium-erosion area $\left(M_{c}\right)$, state fixed effects $\left(\alpha_{s}\right)$, and county characteristics in 1930, 1925, 1920, and $1910\left(X_{c}\right)$ :

$$
Y_{c}=\beta_{1} H_{c}+\beta_{2} M_{c}+\alpha_{s}+\theta X_{c}+\epsilon_{c}
$$

\footnotetext{
${ }^{7}$ The excluded $3.6 \%$ of individuals includes those with missing 1935 location, along with those living in 1935 outside the contiguous US.
} 
Coefficients $\beta_{1}$ and $\beta_{2}$ reflect the difference in migration rates for high-erosion counties and medium-erosion counties, relative to low-erosion counties. By controlling for state fixed effects and pre-1930's county characteristics (as specified in Hornbeck (2012)), ${ }^{8}$ relative impacts of the Dust Bowl are identified from comparing more-eroded counties to less-eroded counties within the same state and with similar pre-1930's characteristics. The identification assumption is that more-eroded counties would otherwise have experienced similar migration as less-eroded counties, and this assumption is more credible when comparing counties within the same state and with similar characteristics in 1930 (and before) that would be affected similarly by other 1930's shocks (e.g., policies, technologies, or changing prices that differentially affect areas growing different crops). This equation does not estimate aggregate effects of the Dust Bowl, as even low-erosion counties may have been affected, but identifies differences in migration intensity.

For estimating average differences between Plains migrants and non-migrants, I regress individual characteristic $Y_{i c}$ on whether that individual moved from a Plains county in 1935 to a different county in $1940\left(\right.$ Migrant $\left._{i}\right)$ and county fixed effects $\left(\gamma_{c}\right)$ :

$$
Y_{i c}=\beta \text { Migrant }_{i}+\gamma_{c}+\epsilon_{i c}
$$

When county fixed effects reflect individuals' 1935 county, the coefficient $\beta$ captures outselection: average differences between Plains migrants and non-migrants from their old origin counties. When county fixed effects reflect individuals' 1940 county, the coefficient $\beta$ captures in-selection: average differences between Plains migrants and natives in their new destination counties throughout the contiguous US.

The main empirical specification estimates how Dust Bowl erosion induced different migrants, combining equations 1 and 2. For example, while migrants may be more-educated than non-migrants in general, the main empirical specification estimates whether this difference was different for Plains migrants from more-eroded counties and Plains migrants from less-eroded counties. I regress individual characteristic $Y_{i c}$ on whether that individual moved from a Plains county in 1935 to a different county in 1940 (Migrant $\left._{i}\right)$, interacted with the

\footnotetext{
${ }^{8}$ This vector of county characteristics includes (in different years): acres of farmland (1930, 1925, 1920, 1910), cropland share of farmland (1930, 1925), population per acre (1930, 1920, 1910), rural population share $(1930,1920,1910)$, on-farm population share (1930), farms per acre $(1930,1925,1920,1910)$, average farm size (1930, 1925, 1920, 1910), individual crop shares of total cropland (1930 and 1925, for five crop categories: corn, wheat, hay, cotton, oats/barley/rye), cows per acre (1930, 1925, 1920, 1910), pigs per acre $(1930,1925,1920,1910)$, chickens per acre $(1930,1925,1920)$. The estimates are not sensitive to also controlling directly for counties' average annual per capita New Deal public works and relief spending and counties' average annual per capita AAA spending (Fishback, Horrace and Kantor, 2006), given the other controls for pre-1930's county characteristics, though New Deal spending is potentially endogenous to 1930's conditions and so these measures are omitted following Hornbeck (2012).
} 
fraction of the 1935 county in a high-erosion area $\left(H_{c}\right)$, the fraction of the 1935 county in a medium-erosion area $\left(M_{c}\right)$, 1935 state fixed effects $\left(\alpha_{s}\right)$ and 1935 county characteristics in 1930, 1925, 1920, and $1910\left(X_{c}\right)$ :

$$
\begin{aligned}
Y_{i c} & =\beta_{1} H_{c} \times \text { Migrant }_{i}+\beta_{2} M_{c} \times \text { Migrant }_{i} \\
& +\alpha_{s} \times \text { Migrant }_{i}+\theta X_{c} \times \text { Migrant }_{i}+\gamma_{c}+\epsilon_{i c}
\end{aligned}
$$

Coefficients $\beta_{1}$ and $\beta_{2}$ indicate how the selection of Plains migrants from high-erosion counties and medium-erosion counties is different than the selection of Plains migrants from lowerosion counties (within the same state and with similar pre-1930's county characteristics). When county fixed effects $\left(\gamma_{c}\right)$ reflect individuals' 1935 county, $\beta_{1}$ and $\beta_{2}$ report how outselection differs for Plains migrants from more-eroded counties relative to Plains migrants from less-eroded counties. By contrast, when county fixed effects $\left(\gamma_{c}\right)$ reflect individuals' 1940 county, $\beta_{1}$ and $\beta_{2}$ report how in-selection differs for Plains migrants from more-eroded counties relative to Plains migrants from less-eroded counties.

For individual-level analysis of migrant characteristics, in equations 2 and 3, standard errors are clustered by 1935 county or two-way clustered by 1935 county and 1940 county. For county-level analysis of migration rates, in equation 1, specifications are weighted by county population in $1935 .^{9}$

\section{Results}

\section{IV.A Migration Rates}

Table 1 reports that 17\% of people moved counties between 1935 and 1940 (Panel A, column 1), among the 6.5 million sample people living in the 843 Plains counties in 1935. This migration rate is 3.1 percentage points higher for people from high-erosion counties (Panel A, column 2) and 1.9 percentage points higher for people from medium-erosion counties (Panel A, column 3), relative to people from low-erosion counties (within the same state and with similar pre-1930's county characteristics). These estimates imply the migration rate is 1.2 percentage points higher for people from high-erosion counties relative to people from medium-erosion counties. ${ }^{10}$

This higher migration from more-eroded counties was concentrated among people moving to counties more than 200 miles from their origin county (Table 1, Panel B). ${ }^{11}$ Over this

\footnotetext{
${ }^{9}$ Adjusting for spatial correlation across counties (Conley, 1999), assuming spatial correlation declines linearly to a distance cutoff and is zero thereafter, estimated standard errors for county-level migration rates are 10-20\% larger for distance cutoffs between 200 and 400 miles.

${ }^{10}$ These estimates are weighted by county population, and are moderately larger when unweighted. The estimates are similar for men and women, separately, with moderately higher migration rates among men.

${ }^{11}$ This distance is measured between county centroids.
} 
period, 7.2\% of people moved more than 200 miles (Column 1), and this migration was higher from more-eroded counties: 2.6 percentage points higher from high-erosion counties (Column 2) and 1.4 percentage points higher from medium-erosion counties (Column 3), relative to low-erosion counties. By contrast, while $9.9 \%$ of people moved to counties within 200 miles (Panel C, Column 1), this movement among nearby counties was more similar from more-eroded and less-eroded counties (Panel C, Columns 2 and 3). Thus, while moving among nearby counties was relatively common over this period, the increase in migrants moving more than 200 miles more directly relates to additional migration induced by higher erosion.

Of particular interest is long-distance migration to California. Overall, $1.65 \%$ of people moved from Plains counties to California (Panel D, Column 1). This migration to California was 0.70 percentage points higher for people from high-erosion counties and 0.51 percentage points higher for people from medium-erosion counties, relative to people from low-erosion counties. $^{12}$ These estimates imply the Dust Bowl induced 64,000 additional migrants to California from high-erosion and medium-erosion counties, relative to low-erosion counties. ${ }^{13}$ This estimate should be lower than aggregate migration to California induced by the Dust Bowl, as the Dust Bowl likely increased migration from low-erosion counties also, but I focus on these additional Dust Bowl migrants from more-eroded counties to distinguish their characteristics from those of other migrants in the 1930's.

For subsequent tables, I define "migrants" as those who moved to counties more than 200 miles from their origin Plains county. This definition excludes those moving across nearby county boundaries, or moving within counties, and focuses on the elevated rates of migration associated with higher Dust Bowl erosion. ${ }^{14}$

\section{IV.B Out-Selection of Dust Bowl Migrants}

Plains migrants were "positively selected," on average, with roughly one more year of education than non-migrants from their 1935 origin county (Table 2, Column 1). This difference is similar for men (1.11 years) and women (1.02 years). Indeed, more-educated people are

\footnotetext{
${ }^{12}$ There was also somewhat elevated migration to the Pacific Northwest (Washington, Oregon, Idaho), though migration to California was substantively larger and has been more central in shaping impressions of Dust Bowl migrants.

${ }^{13}$ This estimate is similar to a scenario of 72,000 additional migrants to California considered by Boustan, Fishback and Kantor (2010), though that number comes from overall migration flows to California from Oklahoma/Texas/Arkansas/Missouri in the 1930s relative to the 1920s (Gregory, 1989). The 64,000 number reflects my estimated relative increase in migration rates multiplied by the total population in high-erosion areas (2.6 million) and medium-erosion areas (8.9 million), calculated from multiplying county populations by the fraction of county area in high-erosion or medium-erosion areas.

${ }^{14}$ This definition of "migrants" also excludes seasonal migrants and return migrants. For Tables 2 and 3, "non-migrants" are those who remained in their 1935 county, though estimates are similar when "nonmigrants" includes those who moved within 200 miles.
} 
generally more geographically mobile in the United States (see, e.g., Bogue and Hagood, 1953, Collins, 2007, Hornbeck and Moretti, 2020). ${ }^{15}$

By contrast, the Dust Bowl induced migration among less-educated people than otherwise would have migrated. Migrants from more-eroded counties were less "positively selected," in years of education, than migrants from less-eroded counties (Columns 2 and 3). Male migrants from high-erosion counties averaged 0.51 fewer years of education relative to nonmigrants from their counties, compared to the difference in years of education between migrants and non-migrants from low-erosion counties within the same state and with similar pre-1930's characteristics.

For interpreting this estimated magnitude, we should consider the fraction of migrants from high-erosion counties that are additional Dust Bowl migrants induced to move by higher erosion. If we assume that higher erosion only induced additional migrants, and did not discourage some from migrating, then estimates from Table 1 imply that additional Dust Bowl migrants were $30 \%$ of all migrants from high-erosion counties (and $18 \%$ of all migrants from medium-erosion counties). ${ }^{16}$ To focus on these additional Dust Bowl migrants, induced to move by higher-erosion, estimates from column 2 would then be scaled-up by 3.33 (1/0.30): male Dust Bowl migrants from high-erosion counties averaged 1.7 fewer years of education relative to non-migrants in high-erosion counties, compared to the difference between migrants and non-migrants from low-erosion counties. ${ }^{17}$ Male Dust Bowl migrants from high-erosion and medium-erosion counties were similarly different $(-1.7$ years and -2.0 years), after scaling the estimates, because the different scaling factors adjust for differences in migration intensity.

Dust Bowl migrants were then "negatively selected" in absolute terms, compared to nonmigrants. Male Dust Bowl migrants from high-erosion counties were less positively selected than migrants from low-erosion counties (-1.7 years), whereas average male migrants were positively selected (1.1 years), implying Dust Bowl migrants also had less education than non-migrants. These estimates are similar for female migrants: whereas migrants were

\footnotetext{
${ }^{15}$ In an early analysis of migration between 1935 and 1940, Bogue and Hagood (1953) highlight this "positive selection of the better educated."

${ }^{16}$ This calculation reflects the estimated increase in migration from high-erosion counties relative to lowerosion counties (Table 1, Column 2, Panel B), as a share of the average migration rate from high-erosion counties (where column 1 reflects a population-weighted average in high-erosion, medium-erosion, and lowerosion counties).

${ }^{17}$ If higher erosion also discouraged some individuals from migrating, then Dust Bowl migrants would be a higher share of all migrants and the implied scaling factor would be closer to one. If all migrants from high-erosion counties would not have migrated had there been less erosion, and different individuals would have migrated, then the non-scaled estimates in Table 2 represent the difference in selection between Dust Bowl migrants and other migrants (along with comparing the selection of all migrants from high-erosion counties to the selection of all migrants from low-erosion counties).
} 
generally positively selected, Dust Bowl migrants were atypical and negatively selected in years of education.

These estimates are similar when considering only migration to California (Columns 4 6). Plains migrants to California averaged more years of education than non-migrants (Column 4), though these migrants were less positively selected than migrants to all counties (Column 1). Migrants to California from more-eroded counties were less positively selected than migrants to California from less-eroded counties (Columns 5 and 6) and Dust Bowl migrants to California were negatively selected, in absolute terms, compared to non-migrants. ${ }^{18}$

Plains migrants were also less likely than non-migrants to have been living in their birth state in 1935 (Column 1), though this was less true for migrants from more-eroded counties than for migrants from less-eroded counties (Columns 2 and 3). In other respects, Dust Bowl migrants were more similar to general migrants: less likely to have lived on a farm in 1935, younger, and more likely male.

\section{IV.C In-Selection of Dust Bowl Migrants}

Dust Bowl migrants' reputation for having been agricultural appears in differences from natives in their new counties (Table 3), more than differences from non-migrants in their origin counties (Table 2). Migrants from more-eroded counties were more likely to have lived on a farm in 1935 than migrants from less-eroded counties, compared to natives in their destination counties (Table 3, Columns 2-3 and 5-6). Further, while all Plains migrants were no more likely than natives to have lived on a farm (Column 1), all Plains migrants to California were 12 percentage points more likely to have lived on a farm in 1935 than natives in their California counties (Column 4). From California natives' perspective: more migrants were arriving from more-eroded counties; all Plains migrants to California had a more agricultural background than natives; and Dust Bowl migrants had a more agricultural background, relative to natives, than was typical of other Plains migrants. By 1940, however, migrants had shifted from agriculture: all Plains migrants became less likely than natives to live on a farm, weakly so in California, and migrants from more-eroded counties were not as disproportionately living on a farm in 1940.

Dust Bowl migrants struggled economically in 1939, relative to natives, and especially in California. This reflects two effects: migrants from more-eroded counties fared worse than migrants from less-eroded counties, and all Plains migrants struggled relative to natives in California especially. Migrants from more-eroded counties had lower incomes and were less educated, relative to natives, than migrants from less-eroded counties (Columns 2-3 and 5-

\footnotetext{
${ }^{18}$ Estimates from Table 1 imply that additional Dust Bowl migrants to California were $35 \%$ of all migrants to California from high-erosion counties (and 29\% of all migrants to California from medium-erosion counties), under the assumption that higher erosion only induced additional migration to California.
} 
6). ${ }^{19}$ There continue to be income differences after controlling for "skill" (years of education, age, age-squared). ${ }^{20}$ Reinforcing this effect, all Plains migrants averaged substantially lower skill-adjusted incomes than natives (especially in California). ${ }^{21}$ Overall, economic struggles associated with "Dust Bowl migrants" reflect average struggles of migrants, relative to natives, along with increased migration from more-eroded counties and worse outcomes for those leaving more-eroded counties.

\section{IV.D Dust Bowl Impact on Wage Incomes}

Given the economic struggles of Dust Bowl migrants, and substantial impacts of Dust Bowl erosion on agricultural land, there are remarkably modest impacts of the Dust Bowl on 1939 wage incomes. Table 4 compares 1939 incomes for all those living in more-eroded counties in 1935 to all those living in less-eroded counties in 1935, within the same state and controlling for pre-1930's county characteristics. Panel A reports that average wage incomes were a statistically insignificant $1.3 \%$ lower for people from high-erosion counties relative to people from low-erosion counties. This estimate is moderately more negative for people from medium-erosion counties and for the smaller number of women working 26+ weeks (Panel B), but the magnitudes are small in contrast to much larger impacts on agricultural land in more-eroded counties. ${ }^{22}$

This analysis pools all migrants and non-migrants, based on their 1935 location, which is necessary because of differential selection into migration and migration destinations. Indeed, previous research was unable to follow migrants, and thereby estimate how people were affected by the Dust Bowl, and so focused on how land was affected by the Dust Bowl (Hornbeck, 2012).

\section{Conclusion}

Dust Bowl migrants are an archetype of environmental refugees, having left areas of the United States' Plains that experienced severe erosion in the 1930's. While impressions of

\footnotetext{
${ }^{19}$ When analyzing impacts on income, the sample is restricted to people working $26+$ weeks (full-time equivalent): $82 \%$ of sample men and $22 \%$ of sample women. As indirect measures of income and consumption, I estimate that migrants from more-eroded counties had lower rental expenditures (for renters) and lower home values (for homeowners).

${ }^{20}$ In California, female migrants from more-eroded counties did not have lower wage incomes, relative to natives, though they worked more weeks. Migrant men worked fewer weeks in 1939, relative to natives, and this difference is similar for male migrants from more-eroded and less-eroded counties.

${ }^{21}$ Plains migrants were generally more educated than natives in their 1940 county, but not in California (Columns 1 and 4).

${ }^{22}$ Hornbeck (2012) estimates much larger declines in agricultural revenues and land values in high-erosion counties $(27 \%$ and $30 \%)$ and medium-erosion counties (16\% and $17 \%)$, relative to low-erosion counties. The 1940 Census reports only wage and salary income in 1939, which would not include impacts on agricultural profits. Given some labor mobility across occupations, however, these estimated impacts on labor income suggest substantially smaller impacts of the Dust Bowl on people than on land.
} 
Dust Bowl migrants influence perceptions of migration responses to environmental collapse and economic upheaval, the Dust Bowl migrants and their experiences are difficult to identify separately from other factors in the 1930's (e.g., the Great Depression, New Deal policies, changing crop prices, agricultural mechanization). These other factors influence both artistic depictions and data analyses of regional migrants.

My analysis compares migrants from more-eroded counties to migrants from less-eroded counties, within the same state and with similar pre-1930's county characteristics, to identify: the relative increase in migration induced by the Dust Bowl; differences in out-selection of those migrants; and differences in in-selection of those migrants. I estimate a substantial migration response to the Dust Bowl that, despite the economic struggles of Dust Bowl migrants, was ultimately associated with remarkably modest impacts of the Dust Bowl on incomes of workers from more-eroded counties in comparison to substantial and enduring impacts of the Dust Bowl on agricultural lands in more-eroded counties.

Dust Bowl migrants were "negatively selected," with fewer years of education, in contrast to general migrants that were "positively selected" and averaged more years of education than non-migrants. In this sense, the Dust Bowl migrants were atypical of general migrants in this era, more pushed from more-eroded counties than pulled to economic opportunities. This atypical selection of migrants suggests why these particular migrants generated unusually hostile local reactions.

I estimate increased migration to California from more-eroded counties, which is only one component of the general migration response to the Dust Bowl, but which has been central to impressions formed of Dust Bowl migrants. These impressions of Dust Bowl migrants partly reflected average migrant experiences in California: migrants generally fared worse than natives, especially in California, and the Dust Bowl increased migration to California such that these average struggles of migrants contributed to the struggles of Dust Bowl migrants. Beyond these average struggles of migrants, however, Dust Bowl migrants from more-eroded counties fared even worse relative to natives than migrants from less-eroded counties (in California and elsewhere). These struggles reflect, in part, the relatively negative selection of Dust Bowl migrants.

Despite these struggles of Dust Bowl migrants, there was ultimately little impact of the Dust Bowl on 1939 wage incomes of those living in more-eroded counties in 1935 relative to those living in less-eroded counties in 1935. Whereas Hornbeck (2012) estimates only slow and limited adaptation of local agricultural production in more-eroded counties, and enduring declines in agricultural land values, the adaptation of workers through out-migration from more-eroded counties was ultimately associated with little average impact on original residents' wage incomes from the permanent collapse of the local environment. 


\section{References}

Abramitzky, Ran, and Leah Platt Boustan. 2017. "Immigration in American Economic History." Journal of Economic Literature, 55(4): 1311-1345.

Abramitzky, Ran, Leah Platt Boustan, and Katherine Eriksson. 2012. "Europe's Tired, Poor, Huddled Masses: Self-Selection and Economic Outcomes in the Age of Mass Migration." American Economic Review, 102(5): 1832-1856.

Bogue, Donald J., and Margaret Jarman Hagood. 1953. Subregional Migration in the United States, 1935-1940. Scripps Foundation, Miami University.

Bohra-Mishra, Pratikshya, Michael Oppenheimer, and Solomon M. Hsiang. 2014. "Nonlinear permanent migration response to climatic variations but minimal response to disasters." PNAS, 111(27): 9780-9785.

Borjas, George J. 1987. "Self-Selection and the Earnings of Immigrants." American Economic Review, 77(4): 531-553.

Boustan, Leah Platt. 2009. "Competition in the Promised Land: Black Migration and Racial Wage Convergence in the North, 1940-1970." Journal of Economic History, 69(3): 756-783.

Boustan, Leah Platt. 2010. "Was Postwar Suburbanization "White Flight"? Evidence from the Black Migration." Quarterly Journal of Economics, 125(1): 417-443.

Boustan, Leah Platt, Matthew E. Kahn, and Paul W. Rhode. 2012. "Moving to Higher Ground: Migration Responpse to Natural Disasters in the Early Twentieth Century." American Economic Review P\&PP, 102(3): 238-244.

Boustan, Leah Platt, Matthew E. Kahn, Paul W. Rhode, and Maria Lucia Yanguas. 2019. "The Effect of Natural Disasters on Economic Activity in US Counties: A Century of Data." NBER Working Paper, 23410.

Boustan, Leah Platt, Price V. Fishback, and Shawn Kantor. 2010. "The Effect of Internal Migration on Local Labor Markets: American Cities during the Great Depression." Journal of Labor Economics, 28(4): 719-746.

Cai, Ruohong, Shuaizhang Feng, Michael Oppenheimer, and Mariola Pytlikova. 2016. "Climate Variability and International Migration: The Importance of the Agricultural Linkage." Journal of Environment Economics and Management, 79: 135-151. 
Cannon, Brian Q. 1996. Remaking the Agrarian Dream: New Deal Rural Resettlement in the Mountain West. University of New Mexico Press.

Collins, William J. 2007. "Education, Migration, and Regional Wage Convergence in American History." In The New Comparative Economic History: Essays in Honor of Jeffrey G. Williamson. , ed. T. J. Hatton, Kevin H. O'Rourke and Alan M. Taylor, Chapter 7, 165-192. MIT Press.

Collins, William J., and Marianne H. Wanamaker. 2014. "Selection and Economic Gains in the Great Migration of African Americans: New Evidence from Linked Census Data." American Economic Journal: Applied Economics, 6(1): 220-252.

Collins, William J., and Marianne H. Wanamaker. 2015. "The Great Migration in Black and White: New Evidence on the Selection and Sorting of Southern Migrants." The Journal of Economic History, 75(4): 947-992.

Conley, Timothy G. 1999. "GMM estimation with cross sectional dependence." Journal of econometrics, 92(1): 1-45.

Derenoncourt, Ellora. 2019. "Can You Move to Opportunity? Evidence from the Great Migration." Working Paper.

Deryugina, Tatyana. 2017. "The Fiscal Cost of Hurricanes: Disaster Aid versus Social Insurance." American Economic Journal: Economic Policy, 9(3): 168-198.

Deryugina, Tatyana, and David Molitor. 2019. "Does When You Die Depend on Where You Live? Evidence from Hurricane Katrina." NBER Working Paper, 24822.

Deryugina, Tayana, Laura Kawano, and Steven Levitt. 2018. "The Economic Impact of Hurricane Katrina on Its Victims: Evidence from Individual Tax Returns." American Economic Journal: Applied Economics, 10(2): 202-233.

Desmet, Klaus, and Esteban Rossi-Hansberg. 2015. "On the Spatial Economic Impact of Global Warming." Journal of Urban Economics, 88: 16-37.

Dewing, Rolland. 2006. Regions in Transition: The Northern Great Plains and the Pacific Northwest in the Great Depression. University Press of America.

Fishback, Price V., William C. Horrace, and Shawn Kantor. 2006. "The Impact of New Deal Expenditures on Mobility During the Great Depression." Explorations in Economic History, 43: 179-222. 
Gregory, James N. 1989. American Exodus. Oxford University Press.

Gutmann, Myron, Daniel Brown, Angela R. Cunningham, James Dykes, Susan Hautaniemi Leonard, Jani Little, Jeremy Mikecz, Paul W. Rhode, Seth Spielman, and Kenneth M. Sylvester. 2016. "Migration in the 1930s: Beyond the Dust Bowl." Social Science History, 40(4): 707-740.

Haines, Michael R. 2010. "Historical, Demographic, Economic, and Social Data: The United States, 1790-2002." ICPSR, 2896.

Hansen, Zeynep K., and Gary D. Libecap. 2004. "Small Farms, Externalities, and the Dust Bowl of the 1930s." Journal of Politial Economy, 112(3): 665-694.

Hornbeck, Richard. 2010. "Barbed Wire: Property Rights and Agricultural Development." Quarterly Journal of Economics, 125(2): 767-810.

Hornbeck, Richard. 2012. "The Enduring Impact of the American Dust Bowl: Shortand Long-Run Adjustments to Environmental Catastrophe." American Economic Review, 102(4): 1477-1507.

Hornbeck, Richard, and Enrico Moretti. 2020. "Estimating Who Benefits From Productivity Growth: Local and Aggregate Effects of City TFP Shocks on Wages, Rents, and Inequality." Working Paper.

Janow, Seymour J., and Davis McEntire. 1940. "Migration to California." Land Policy Review, 24-36.

Long, Jason, and Henry Siu. 2018. "Refugees from Dust and Shrinking Land: Tracking the Dust Bowl Migrants." Journal of Economic History, 78(4): 1001-1033.

Lookingbill, Brad D. 2001. Dust Bowl USA: Depression America and Ecological Imagination. Ohio University Press.

Mahajan, Parag, and Dean Yang. 2020. "Taken by Storm: Hurricanes, Migrant Networks, and US Immigration." American Economic Journal: Applied Economics, 12(2): 250-277.

Marchiori, Luca, Jean-Françcois Maystadt, and Ingmar Schumacher. 2012. "The Impact of Weather Anomalies on Migration in sub-Saharan Africa." Journal of Environmental Economics and Management, 63: 355-374. 
McWilliams, Carey. 1942. Ill Fares the Land: Migrants and Migratory Labor in the United States. Little, Brown.

Piguet, Etienne, Antoine Pécoud, and Paul de Guchteneire. 2011. "Migration and Climate Change: An Overview." Refugee Survey Quarterly, 30(3): 1-24.

Roy, A. D. 1951. "Some Thoughts on the Distribution of Earnings." Oxford Economic Papers, 3(2): 135-146.

Shindo, Charles J. 1997. Dust Bowl Migrants in the American Imagination. University Press of Kansas.

Spitzer, Yannay, Gaspare Tortorici, and Ariell Zimran. 2020. "International Migration Responses to Natural Disasters: Evidence from Modern Europe's Deadliest Earthquake." NBER Working Paper, 27506.

Stein, Walter J. 1973. California and the Dust Bowl Migration. Greenwood Press.

Stern, Nicholas. 2007. The Economics of Climate Change: The Stern Review. Cambridge University Press.

Stuart, Bryan A., and Evan J. Taylor. 2019. "Migration Networks and Location Decisions: Evidence from U.S. Mass Migration." American Economic Journal: Applied Economics, forthcoming.

Troxell, Willard W., and W. Paul O'Day. 1940. "Migration to the Pacific Northwest 1930-1938." Land Policy Review, 32-43. 
Figure 1. The 843 Plains Counties, Shaded by Erosion Level

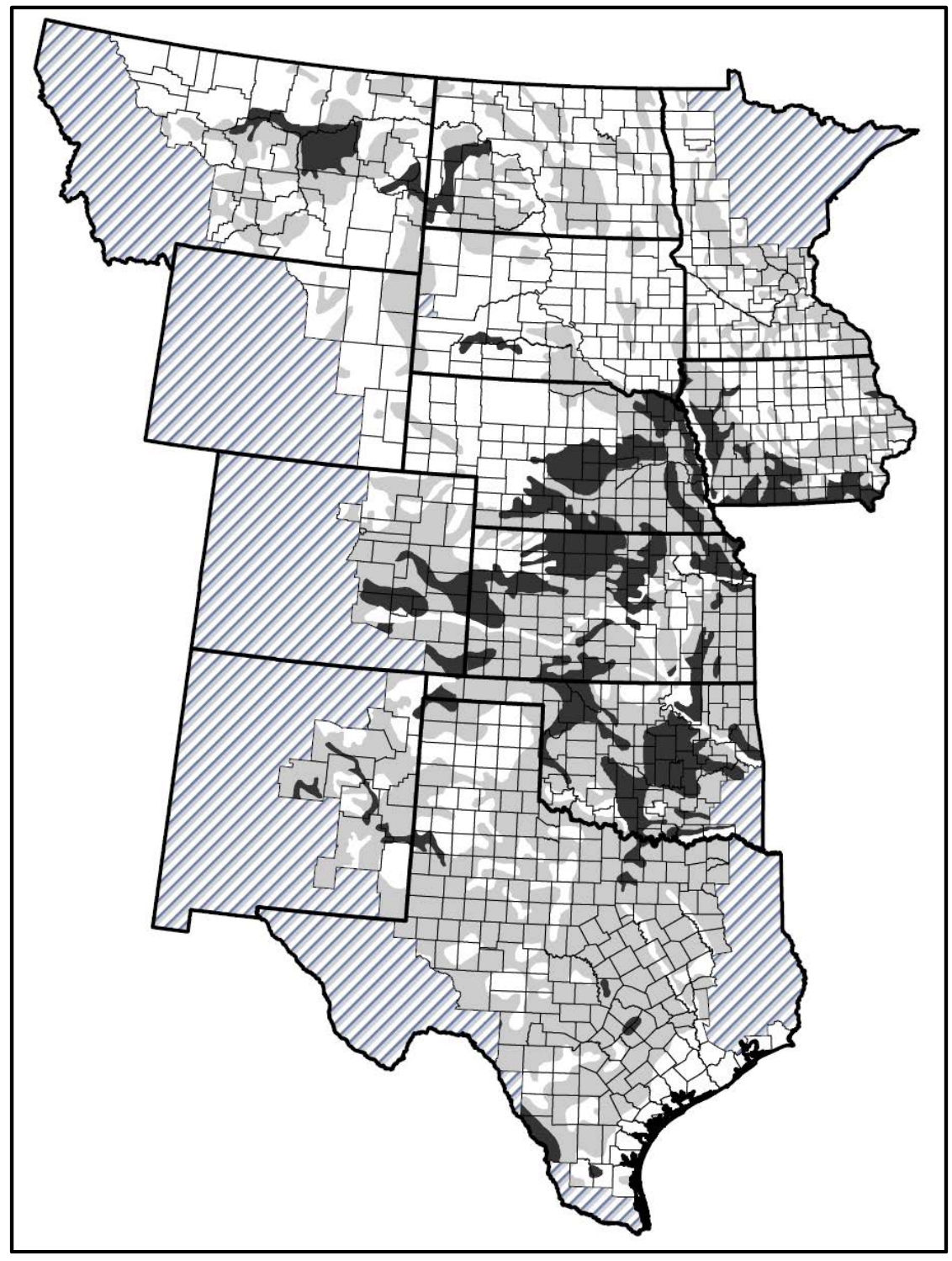

Notes: The mapped erosion levels are low (shaded white, less than 25\% of topsoil lost), medium (shaded light gray, $25 \%$ to $75 \%$ of topsoil lost), or high (shaded dark gray, more than $75 \%$ of topsoil lost). Thin lines denote 1940 county borders, corresponding to 843 counties in this Plains region. Thick lines denote state boundaries. Crossed out areas are not in the Plains region. The Plains region is defined to be this contiguous set of 843 counties from these 12 States (Colorado, Iowa, Kansas, Minnesota, Montana, Nebraska, New Mexico, North Dakota, Oklahoma, South Dakota, Texas, and Wyoming) that have 50 percent or more of their area in the typical central United States grassland and forest vegetation regions (Tall Grass, Short Grass, Mesquite Grass, Mesquite and Desert Grass Savanna, and Oak-Hickory Forest) as mapped by the USDA's 1924 Atlas of Agriculture. Source: National Archives (College Park, MD), RG 114, Cartographic Records of the Soil Conservation Service, \#149. 
Table 1. Estimated Migration From 1935 to 1940, by Original County Erosion Level

\begin{tabular}{lccc}
\hline & All Plains & \multicolumn{2}{c}{ Relative to Low Erosion Counties: } \\
\cline { 3 - 4 } & $\begin{array}{c}\text { Counties } \\
(1)\end{array}$ & $\begin{array}{c}\text { High-Erosion } \\
\text { Counties } \\
(2)\end{array}$ & $\begin{array}{c}\text { Medium-Erosion } \\
\text { Counties } \\
(3)\end{array}$ \\
\hline Panel A. Migration To All Counties & 17.05 & 3.05 & 1.86 \\
Migration Percent & {$[5.19]$} & $(0.64)$ & $(0.46)$ \\
\hline Panel B. Migration Beyond 200 Miles & & & 1.38 \\
Migration Percent & 7.19 & 2.57 & $(0.33)$ \\
\hline Panel C. Migration Within 200 Miles & {$[3.82]$} & $(0.56)$ & 0.47 \\
Migration Percent & & & $(0.28)$ \\
\hline Panel D. Migration to California & 9.86 & 0.47 & 0.51 \\
Migration Percent & {$[3.41]$} & $(0.38)$ & $(0.09)$ \\
\hline Panel E. Migration to Pacific Northwest & 1.65 & 0.70 & 0.14 \\
Migration Percent & {$[1.15]$} & $(0.12)$ & $(0.09)$ \\
\hline \hline
\end{tabular}

Notes: For 843 Plains counties (Figure 1), county-level migration rates are defined for all individuals residing in these counties in 1935, ages 25 to 55 in 1935, that report county of residence in 1935 and 1940. Panel A reports the number of migrants leaving a county between 1935 and 1940, as a percent of that county's sample population in 1935. Panel B reports the corresponding number for migrants who leave their county and move to a county further than 200 miles away, and Panel $\mathrm{C}$ reports the corresponding number for migrants who leave their county and move to a county within 200 miles. Panel D reports the number of migrants going to California, as a percent of 1935 county sample population. Panel E reports the number of migrants going to the Pacific Northwest (Washington, Oregon, Idaho) as a percent of 1935 county sample population.

Column (1) reports the average across all 843 Plains counties, weighting by county population in 1935, with standard deviations reported in brackets. For each row, columns (2) and (3) report the coefficients from a regression of the migration percent on the fraction of the county in a high-erosion area and the fraction of the county in a medium-erosion area (lowerosion is the omitted category), controlling for state fixed effects and a vector of county-level characteristics in 1930, 1925, 1920, and 1910 (from Hornbeck 2012). These county-level regressions are weighted by county population in 1935, and robust standard errors are reported in parentheses. 
Table 2. Estimated Out-selection of Migrants, by Original County Erosion Level

\begin{tabular}{|c|c|c|c|c|c|c|}
\hline \multirow[b]{2}{*}{ Outcome: } & \multicolumn{3}{|c|}{ Migrants to All Counties } & \multicolumn{3}{|c|}{ Migrants to California Counties Only } \\
\hline & $\begin{array}{l}\text { Migrants from } \\
\text { All Plains } \\
\text { Counties } \\
(1)\end{array}$ & $\begin{array}{l}\text { Relative to } \\
\text { Migrants from } \\
\text { High-Erosion } \\
\text { Counties } \\
\text { (2) }\end{array}$ & $\begin{array}{l}\text { ow-Erosion: } \\
\text { Migrants from } \\
\text { Med-Erosion } \\
\text { Counties } \\
\text { (3) }\end{array}$ & $\begin{array}{l}\text { Migrants from } \\
\text { All Plains } \\
\text { Counties } \\
\text { (4) }\end{array}$ & $\begin{array}{l}\text { Relative to } \\
\text { Migrants from } \\
\text { High-Erosion } \\
\text { Counties } \\
\text { (5) }\end{array}$ & $\begin{array}{l}\text { Mw-Erosion: } \\
\text { Migrants from } \\
\text { Med-Erosion } \\
\text { Counties } \\
\text { (6) }\end{array}$ \\
\hline \multicolumn{7}{|l|}{ Years of Education } \\
\hline Men & $\begin{array}{c}1.11 \\
(0.06)\end{array}$ & $\begin{array}{l}-0.51 \\
(0.13)\end{array}$ & $\begin{array}{l}-0.37 \\
(0.10)\end{array}$ & $\begin{array}{c}0.54 \\
(0.08)\end{array}$ & $\begin{array}{l}-0.56 \\
(0.13)\end{array}$ & $\begin{array}{l}-0.36 \\
(0.10)\end{array}$ \\
\hline Women & $\begin{array}{c}1.02 \\
(0.05)\end{array}$ & $\begin{array}{l}-0.44 \\
(0.13)\end{array}$ & $\begin{array}{l}-0.37 \\
(0.10)\end{array}$ & $\begin{array}{c}0.48 \\
(0.07)\end{array}$ & $\begin{array}{l}-0.49 \\
(0.13)\end{array}$ & $\begin{array}{l}-0.38 \\
(0.11)\end{array}$ \\
\hline $\begin{array}{l}\text { Percent Living in } \\
\text { Birth State in } 1935\end{array}$ & $\begin{array}{l}-8.47 \\
(0.64)\end{array}$ & $\begin{array}{c}2.63 \\
(1.35)\end{array}$ & $\begin{array}{c}1.92 \\
(1.02)\end{array}$ & $\begin{array}{l}-2.84 \\
(0.69)\end{array}$ & $\begin{array}{c}1.11 \\
(1.53)\end{array}$ & $\begin{array}{c}1.14 \\
(1.08)\end{array}$ \\
\hline $\begin{array}{l}\text { Percent Living on } \\
\text { a Farm in } 1935\end{array}$ & $\begin{array}{l}-9.79 \\
(0.68)\end{array}$ & $\begin{array}{c}1.34 \\
(1.40)\end{array}$ & $\begin{array}{c}0.93 \\
(0.98)\end{array}$ & $\begin{array}{l}-8.80 \\
(0.91)\end{array}$ & $\begin{array}{c}2.31 \\
(1.69)\end{array}$ & $\begin{array}{c}0.79 \\
(1.36)\end{array}$ \\
\hline Age & $\begin{array}{l}-2.95 \\
(0.04)\end{array}$ & $\begin{array}{c}0.08 \\
(0.14)\end{array}$ & $\begin{array}{l}-0.10 \\
(0.10)\end{array}$ & $\begin{array}{l}-2.75 \\
(0.04)\end{array}$ & $\begin{array}{c}0.23 \\
(0.20)\end{array}$ & $\begin{array}{l}-0.07 \\
(0.16)\end{array}$ \\
\hline Percent Male & $\begin{array}{c}3.65 \\
(0.21)\end{array}$ & $\begin{array}{c}-0.32 \\
(0.40)\end{array}$ & $\begin{array}{l}-0.45 \\
(0.32)\end{array}$ & $\begin{array}{c}1.62 \\
(0.29)\end{array}$ & $\begin{array}{l}-0.70 \\
(0.57)\end{array}$ & $\begin{array}{l}-0.44 \\
(0.51)\end{array}$ \\
\hline
\end{tabular}

Notes: For Columns 1 - 3, a migrant is someone who lived in different counties in 1935 and 1940 (at least 200 miles apart) and a non-migrant is someone who lived in the same county in 1935 and 1940. The sample is restricted to people who lived in 1935 within the 843 Plains counties (Figure 1). For Columns 4 - 6, the definition of migrants is further restricted to those who migrated to counties in California between 1935 and 1940.

For the indicated outcome variable (in rows): column 1 reports the estimated coefficient on a "migrant" indicator, controlling for 1935 county fixed effects. Columns 2 and 3 report coefficients on the "migrant" indicator, interacted with the fraction of the person's 1935 county in a high-erosion area and medium-erosion area (low-erosion is the omitted category), and controlling for: 1935 county fixed effects, interactions between the "migrant" indicator and 1935 state fixed effects, and interactions between the "migrant" indicator and 1935 county characteristics (in 1930, 1925, 1920, 1910). Columns 4 - 6 report analogous estimates, but restricting the definition of migrant to include only those who migrated to counties in California.

For these individual-level regressions, robust standard errors clustered by 1935 county are reported in parentheses. 
Table 3. Estimated In-selection of Migrants, by Original County Erosion Level

\begin{tabular}{|c|c|c|c|c|c|c|}
\hline \multirow[b]{3}{*}{ Outcome: } & \multicolumn{3}{|c|}{ Migrants to All Counties } & \multicolumn{3}{|c|}{ Migrants to California Counties Only } \\
\hline & \multicolumn{3}{|c|}{ Relative to Low-Erosion: } & & \multicolumn{2}{|c|}{ Relative to Low-Erosion: } \\
\hline & $\begin{array}{l}\text { Migrants from } \\
\text { All Plains } \\
\text { Counties } \\
\text { (1) }\end{array}$ & $\begin{array}{l}\text { Migrants from } \\
\text { High-Erosion } \\
\text { Counties } \\
\text { (2) }\end{array}$ & $\begin{array}{l}\text { Migrants from } \\
\text { Med-Erosion } \\
\text { Counties } \\
\text { (3) }\end{array}$ & $\begin{array}{l}\text { Migrants from } \\
\text { All Plains } \\
\text { Counties } \\
\text { (4) }\end{array}$ & $\begin{array}{l}\text { Migrants from } \\
\text { High-Erosion } \\
\text { Counties } \\
\text { (5) }\end{array}$ & $\begin{array}{c}\text { Migrants from } \\
\text { Med-Erosion } \\
\text { Counties } \\
\text { (6) }\end{array}$ \\
\hline \multicolumn{7}{|c|}{ Percent Living on a Farm } \\
\hline \multirow[t]{2}{*}{ in 1935} & 0.81 & 3.22 & 2.03 & 12.00 & 3.69 & 2.00 \\
\hline & $(1.74)$ & $(1.31)$ & $(0.99)$ & $(1.74)$ & $(1.37)$ & $(0.99)$ \\
\hline \multirow[t]{2}{*}{ in 1940} & -5.01 & 0.98 & 0.82 & -1.67 & 2.50 & 0.16 \\
\hline & $(0.70)$ & $(0.79)$ & $(0.64)$ & $(1.11)$ & (1.16) & $(1.12)$ \\
\hline \multicolumn{7}{|c|}{ Years of Education } \\
\hline \multirow[t]{2}{*}{ Men } & 1.14 & -0.35 & -0.28 & -0.02 & -0.24 & -0.25 \\
\hline & $(0.15)$ & $(0.17)$ & $(0.09)$ & $(0.12)$ & $(0.12)$ & $(0.07)$ \\
\hline \multirow[t]{2}{*}{ Women } & 1.12 & -0.26 & -0.29 & 0.05 & -0.15 & -0.25 \\
\hline & $(0.15)$ & $(0.14)$ & $(0.08)$ & $(0.13)$ & $(0.11)$ & $(0.09)$ \\
\hline \multicolumn{7}{|c|}{ Log Income in 1939} \\
\hline \multirow[t]{2}{*}{ Men } & -0.017 & -0.078 & -0.071 & -0.340 & -0.077 & -0.042 \\
\hline & $(0.039)$ & $(0.029)$ & $(0.017)$ & $(0.031)$ & $(0.033)$ & $(0.023)$ \\
\hline \multirow[t]{2}{*}{ Women } & -0.156 & -0.073 & -0.044 & -0.380 & 0.001 & -0.021 \\
\hline & $(0.047)$ & $(0.040)$ & $(0.021)$ & $(0.017)$ & $(0.038)$ & $(0.024)$ \\
\hline \multicolumn{7}{|c|}{ Log Income in 1939, Skill-Adjusted } \\
\hline \multirow[t]{2}{*}{ Men } & -0.093 & -0.050 & -0.049 & -0.318 & -0.062 & -0.026 \\
\hline & $(0.025)$ & $(0.022)$ & $(0.013)$ & $(0.026)$ & $(0.028)$ & $(0.020)$ \\
\hline \multirow[t]{2}{*}{ Women } & -0.214 & -0.052 & -0.031 & -0.346 & 0.009 & -0.021 \\
\hline & $(0.028)$ & $(0.024)$ & $(0.018)$ & $(0.009)$ & $(0.033)$ & $(0.025)$ \\
\hline \multicolumn{7}{|c|}{ Weeks Worked } \\
\hline \multirow[t]{2}{*}{ Men } & -2.16 & -0.14 & -0.01 & -4.92 & -0.19 & 0.31 \\
\hline & $(0.25)$ & $(0.29)$ & $(0.19)$ & $(0.80)$ & $(0.56)$ & $(0.41)$ \\
\hline \multirow[t]{2}{*}{ Women } & -0.48 & 0.25 & 0.47 & 0.25 & 0.83 & 0.44 \\
\hline & $(0.30)$ & $(0.42)$ & $(0.26)$ & $(0.57)$ & $(0.43)$ & $(0.36)$ \\
\hline
\end{tabular}

Notes: For Columns 1 - 3, a migrant is someone who lived in different counties in 1935 and 1940, at least 200 miles apart, and lived in 1935 within the 843 Plains counties (Figure 1). A non-migrant is someone who lived in the same county in 1935 and 1940, within all counties in the contiguous United States. For Columns 4 - 6, the sample is further restricted to migrants from the 843 Plains counties to California and non-migrants in California counties only.

For the indicated outcome variable (in rows): column 1 reportes the estimated coefficient on a "migrant" indicator, controlling for 1940 county fixed effects. Columns 2 and 3 report coefficients on the "migrant" indicator, interacted with the fraction of the person's 1935 county in a high-erosion area and medium-erosion area (low-erosion is the omitted category), and controlling for: 1940 county fixed effects, interactions between the "migrant" indicator and 1935 state fixed effects, and interactions between the "migrant" indicator and 1935 county characteristics. Skill-adjusted income is defined by controlling for individuals' years of education, age, and age-squared.

For these individual-level regressions, robust standard errors two-way clustered by 1935 county and 1940 county are reported in parentheses. 
Table 4. Estimated Log Income Differences in 1939, by Original County Erosion Level

\begin{tabular}{|c|c|c|c|}
\hline \multirow{3}{*}{\multicolumn{2}{|c|}{\begin{tabular}{|l} 
\\
Average \\
Income \\
(1)
\end{tabular}}} & \multicolumn{2}{|c|}{ Relative to Low-Erosion Counties: } \\
\hline & & $\begin{array}{l}\text { High-Erosion } \\
\text { Counties } \\
\text { (3) }\end{array}$ & $\begin{array}{c}\text { Medium-Erosion } \\
\text { Counties } \\
\text { (2) }\end{array}$ \\
\hline & & & \\
\hline Men and Women & $\begin{array}{r}\$ 1,220 \\
{[882]}\end{array}$ & $\begin{array}{c}-0.013 \\
(0.027)\end{array}$ & $\begin{array}{c}-0.028 \\
(0.016)\end{array}$ \\
\hline \multicolumn{4}{|c|}{ Panel B. All 1935 Residents of the Plains, by Gender } \\
\hline Men & $\begin{array}{r}\$ 1,316 \\
{[923]}\end{array}$ & $\begin{array}{c}-0.007 \\
(0.031)\end{array}$ & $\begin{array}{l}-0.028 \\
(0.018)\end{array}$ \\
\hline Women & $\begin{array}{l}\$ 847 \\
{[559]}\end{array}$ & $\begin{array}{l}-0.041 \\
(0.023)\end{array}$ & $\begin{array}{c}-0.028 \\
(0.014)\end{array}$ \\
\hline
\end{tabular}

Notes: The sample includes all people who were living in 1935 within the 843 Plains counties (Figure 1), ages 25 to 55 in 1935, who report county of residence in 1935 and 1940, and report working 26+ weeks in 1939

(equivalent full-time weeks). Panel A reports estimates for a pooled sample of men and women, interacting all control variables with gender, and Panel B reports estimates separately by gender. Column 1 reports average 1939 wage and salary income, in levels, with standard deviations reported in brackets. Columns 2 and 3 report the coefficients from regressing log income on the fraction of the person's 1935 county in a high-erosion area and medium-erosion area (low-erosion is the omitted category), controlling for 1935 state fixed effects and 1935 county characteristics (in 1930, 1925, 1920, and 1910). For these individual-level regressions, robust standard errors two-way clustered by 1935 county and 1940 county are reported in parentheses. 